\title{
Analysis of Factors Affecting the Implementation of Nutrition Awareness Family (Kadarzi) in Tanjung Village Klego Sub-district Boyolali Regency Central Java Province
}

\author{
Mujahidatul Musfiroh ${ }^{1}$, Aprilia Andarwati ${ }^{2}$, \\ \{mujahidatul_m@staff.uns.ac.id ${ }^{1}$, \\ fachaaq@yahoo.co.id $\left.{ }^{2}\right\}$ \\ Midwifery Department, Faculty of Medicine, Universitas Sebelas Maret, Surakarta, Indonesia, ${ }^{1}$ \\ Health Department of Gunung Kidul Regency ${ }^{2}$
}

\begin{abstract}
The nutrition awareness family is the family effort to improve their nutritional status. The efforts could be through monitoring regular weighing, giving exclusive breastfeeding, consuming various foods, using iodized salt, and consuming vitamin A. This research aims to analyse the factors influencing the implementation of nutrition awareness family. The study used analytic observational study with a cross-sectional design. The samples obtained was 176 that met the restriction criteria of purposive sampling. The data collection was done through interview, body weighing, and the iodized salt checking. Two applied tests were chi-square analysis for bivariate analysis test and logistic regression analysis for multivariate analysis test. The bivariate analysis shows the factors influencing the behaviour of nutrition awareness family were the mother's age ( $\mathrm{p}=0,000$ and $\mathrm{OR}=14,841)$, mother's education $(\mathrm{p}=0,000$ and $\mathrm{OR}=3,701)$, mother's employment $(\mathrm{p}=0,000$ and $\mathrm{OR}=0,164)$ and the birth spacing $(\mathrm{p}=0,000$ and $\mathrm{OR}=0,095)$. The multivariate test performs the mother's age $(\mathrm{OR}=9,732)$, mother's education $(\mathrm{OR}=2,627)$, mother's employment $(\mathrm{OR}=0,373)$, and birth spacing factor $(\mathrm{OR}=0,244)$ simultaneously influenced the behaviour of nutrition awareness family. The result of the research indicates that the mentioned factors influence the behaviour of nutrition awareness family. The factor giving the greatest influence on the behaviour of nutrition awareness family is the mother's age.
\end{abstract}

Keywords: Behaviuor of nutrition awareness, family, birth spacing, mother's age, mother's education, and employment.

\section{Introduction}

Nutrition Awareness family is one of the prioritized targets to attain the strategic plan set up by the Health Department of Republic Indonesia. The family has the behavior of KADARZI is the family that has done the good nutrition behavior in which the indicators are monitoring body weighing, giving exclusive breastfeeding, consuming various foods, and supplementing vitamin A capsule (based on government program through Posyandu) [1].

Based on the observation of nutrition status conducted by the Ministry of Health Republic Indonesia in 2017 , there was an increase in malnutrition percentage from 3,40 to 3,80 in the 
children aged 0-59 months. The percentage increase from 1,47 to 1,80 also occurred to the toddler with overnutrition. Indonesia encounters two nutritional problems, namely malnutrition and overnutrition [2]. These multiple nutritional problems can be handled by implementing the behavior of KADARZI. KADARZI behavior is aimed at managing the family members to recognize, prevent, and overcome the nutritional problems for each family member [1].

KADARZI behavior is one of the health preservations aim to prevent nutritional problems in the toddlers. Nutrition Awareness Family (KADARZI) is one of the priority targets to attain the strategic plan enacted by the Department of Health of Indonesian Republic since 2005 stated in National Medium Term Development Plan (RPJMN) concerning in the field of health. Building all families to be the Nutrition Awareness Family is the objective of Desa Siaga (Alert Village) where the people has the readiness in providing the resources and the ability to prevent as well as overcome the health problems. The behavior of nutrition awareness family is an attempt to the family in maintaining the health by knowing, preventing, and overcoming the nutrition problems for each family member.[1] In the national scope, the indicator of Nutrition Awareness Family (KADARZI) has not been well-applied. It can be seen from the health profile of Indonesia in 2014 in which the toddler that has been weighed was $80,8 \%$, the provision of exclusive breastfeeding was $52,3 \%$, and the provision of vitamin A for the toddler was $85,5 \%$ [3]. The proportion of household that consumes the iodized salt was $77,1 \%$ in which the tendency of the household that consumes the iodized salt in the rural area was lower than those in the urban ${ }^{3}$. There is no research that shows the variety of food fora toddler in the national scope. However, the result of the research shows that $24,4 \%$ of the toddlers in Indonesia consume the energy which is less than the minimum needs [4].

KADARZI behavior is influenced by the age and the employment of the mother or nanny [5], [6]. In addition to the age and educational level, KADARZI behavior is also affected by the status of the mother's employment [5]. The implementation of KADARZI behavior is also influenced by the children's birth spacing. The adequate birth spacing that can optimize the care given to children and the children care behavior is included in KADARZI behavior [7].

This study was aimed at analyzing the factors influencing the implementation of nutrition awareness family behavior. The research result is expected to be the benchmark of KADARZI implementation in the family with toddlers. Therefore, the implementation can be optimized based on the condition of the mother and the toddler in the community. The family with toddlers is expected to receive the counseling program, education, and information about KADARZI behavior. The implementation of good KADARZI behavior can solve the nutritional problems in the community by optimizing the role of the family.

\section{Materials and Method}

This research is included in analytical observational study with cross-sectional design. This research was carried out in Tanjung Village, Klego Sub-district, Boyolali regency. The population of this research was the family with toddler aged 6-59 months that live in Tanjung Village, Klego Sub-district, Boyolali Regency in 2016 as many as 315 families. The sample of this research was taken using purposive sampling technique. The sample was chosen by determining the village that has the family with toddler aged 6-59 months that suffer from a large number of abnormal nutrition and five Integrated Health Care Post (Posyandu). The samples taken from the targeted Posyandu were 187 respondents. Purposive sampling 
technique was chosen to focus on the investigation in the family with toddler aged 6-69 months that live in the areas of nutritional problem cases.

The instrument that was used in this research was the questionnaire containing the questions about the respondents' identities (name, age, education, activity, and home address), toddlers' identities (name, age, weight, gender, food that must be avoided by the toddlers). The research questionnaire is also completed by the lists to evaluate the implementation of five indicators of KADARZI that covers the regular weighing, the provision of exclusive breastfeeding, the provision of a variety of foods, the use of iodized salt, the provision of vitamin A. The research process was started by proposing the research permission, determining the research respondents, and collecting the data. Collecting the data was conducted by visiting Posyandu (Community Health Service) that has the nutritional problem cases. After collecting the data of Posyandu that has nutritional problem cases, the data collection was done by distributing the questionnaire about the implementation of KADARZI behavior and by doing a direct interview with the respondents. The behavior of KADARZI in this research was determined by doing the observation of the family's behavior towards five indicators of KADARZI (regular weighing, the provision of exclusive breastfeeding, the provision of a variety of foods, the use of iodized salt, the provision of vitamin A). KADARZI is categorized as good if those five indicators are done well, while it is categorized as fair if one or more indicator of those five indicators were not completed. This research only used the two categories of KADARZI behavior: good and fair. The behavior of KADARZI in this research is categorized as good if the five indicators are completed. If one of those indicators is not completed, then the behavior of KADARZI is categorized as fair

The analysis of research data used chi-square analysis test to determine the relationship between the variables of the mother's age, mother's education, mother's employment, and birth spacing and KADARZI behavior. Further, logistic regression analysis test was to determine the factors influencing the implementation of KADARZI behavior in the family with toddler aged 6-59 months.

\section{Results}

\subsection{Result of Bivariate Analysis Test}

Table 1. The correlation between the behavior of KADARZI and Mother's Age

\begin{tabular}{|c|c|c|c|c|}
\hline \multirow{2}{*}{\multicolumn{2}{|c|}{ Variable }} & \multicolumn{2}{|c|}{ KADARZI behavior } & \multirow[b]{2}{*}{ Total } \\
\hline & & Less Good & Good & \\
\hline \multirow[t]{2}{*}{ Mother's age } & Non Productive & 34 & 18 & 52 \\
\hline & Productive & 14 & 110 & 124 \\
\hline \multicolumn{2}{|c|}{ Total } & 48 & 128 & 176 \\
\hline
\end{tabular}

Table 1 shows that the mother's age is categorized into two: productive age (20-35 years old) and non-productive age ( $<20$ years and $>35$ years). The number of mother in the productive category is 124 respondents. The number of mother in a productive category that has good KADARZI behavior is 110 respondents.

Table 2. The correlation between the behavior of KADARZI and Mother's Education

\begin{tabular}{lccc}
\hline \multirow{2}{*}{ Variable } & \multicolumn{2}{c}{ KADARZI behavior } & Total \\
\cline { 2 - 3 } & Less Good & Good & \\
\hline
\end{tabular}




\begin{tabular}{lcccc}
\hline Mother's & Low & 27 & 33 & 60 \\
Education & High & 21 & 95 & 116 \\
& Total & 48 & 128 & 176 \\
\hline
\end{tabular}

Table 2 shows that the mother's education is categorized into two: a mother with a low level of education (primary school and junior high school graduates) and mother with high level of education (senior high school and university graduates). The number of a mother with a high level of education is 116 respondent. Of the total, 95 respondents have good KADARZI behavior.

Table 3. The correlation between the behavior of KADARZI and Mother's Employment Status

\begin{tabular}{lcccc}
\hline & \multirow{2}{*}{ Variable } & \multicolumn{2}{c}{ KADARZI behavior } & \multirow{2}{*}{ Total } \\
\cline { 2 - 4 } & Unemployed & Less Good & Good & \\
\hline Mother's & 15 & 94 & 109 \\
employment & Employed & 33 & 34 & 67 \\
& Total & 48 & 128 & 176 \\
\hline
\end{tabular}

Table 3 shows that the mother's employment status is categorized into two: unemployed and employed. The number of unemployed mothers is 109 respondents. The unemployed mother that has good KADARZI behavior is 94 respondents.

Table 4. The correlation between the behavior of KADARZI and Mother's Birth Spacing

\begin{tabular}{lcccc}
\hline \multirow{2}{*}{ Variable } & \multicolumn{2}{c}{ KADARZI behavior } & \multirow{2}{*}{ Total } \\
\cline { 3 - 4 } & & Less good & Good & \\
\hline Children Birth & Favorable & 10 & 94 & 104 \\
Spacing & Unfavorable & 38 & 34 & 72 \\
& Total & 48 & 128 & 176 \\
\hline
\end{tabular}

Table 4 shows that the children birth spacing is categorized into two: favorable (the only child in the family and the birth spacing is $>=2$ years per child) and unfavorable (birth spacing is $<2$ years per child). The number of children birth spacing that is in no risks category is 104 respondents. Of the total, 94 respondents have good KADARZI behavior.

Table 5 The Result of Bivariate Analysis

\begin{tabular}{lcc}
\hline \multicolumn{1}{c}{ Variable } & Significance (5\%) & Odds Ratio \\
\hline Mother's age & 0.000 & 14.841 \\
Mother's education & 0.000 & 3.701 \\
Mother's employment & 0.000 & 0.164 \\
Children birth spacing & 0.000 & 0.095 \\
\hline
\end{tabular}

Table 5 shows that the result of bivariate analysis between the variable of mother's age, mother's education, mother's employment, children birth spacing, and KADARZI behavior. The bivariate analysis that used Chi-Square test indicates that there is the relationship between mother's age, mother's education, mother's employment, children birth spacing, and KADARZI behavior. The mother's age in the productive category has the possibility of 
14.841 times to have good KADARZI behavior. The mother's education in a high level of education category has the possibility of 3,701 times to have good KADARZI behavior. Mother's employment in the employed category has the possibility of 0,164 times to have good KADARZI behavior. The children birth spacing less than 2 years has the possibility of 0,095 times to have good KADARZI behavior.

\subsection{The Result of Multivariate Analysis}

Table 6. Result of Multivariate Analysis

\begin{tabular}{lcc}
\hline \multicolumn{1}{c}{ Variable } & Significance $(5 \%)$ & Odds Ratio \\
\hline Mother's Age & 0.000 & 9.732 \\
Mother's Education & 0.048 & 2.627 \\
Mother's employment & 0.037 & 0.373 \\
Children Birth Spacing & 0.003 & 0.244 \\
\hline
\end{tabular}

Table 6 shows the result of multivariate analysis test between the table of mother's age, mother's education, mother's employment, children birth spacing, and KADARZI behavior. A multivariate analysis that used logistic regression indicates that the variable of mother's age, mother's education, mother's employment, children birth spacing simultaneously influence KADARZI behavior. Mother's age has the risks of 9.732 times to influence good KADARZI behavior. It is evidenced by the risk of the mother's education is 2.627 times, mother's employment is 0.373 times, and children birth spacing is 0.244 times. The result of multivariate analysis is that the mother's age is the greatest factor influencing KADARZI behavior.

\section{Discussion}

The result shows that mother's age, mother's education, mother's employment, and children birth spacing are the factors influencing the implementation of KADARZI behavior. The mother's age is majorly the productive age (20-35 years old). The age ranged from 20-35 years old is categorized as an adult. The individual stepping in adult phase has the level of maturity in thinking, so the behavior which is shown leads to the supporting behavior that is underlain by the deep thought [6]. The maturity age shows better behavior in providing the foods for the family [6]. The increase in age can influence the quantity of information received by an individual. The information received by an individual is the experience influencing the individual's behavior scheme. Age influences the building of an individual's ability, which is taken from the daily experience [7].

The level of mother's education influences the mother's behavior development. The mother with a high level of education finds it easier to receive information and new values. Information and new values influence the mother's behavior development [8]. The supportive attitude leads to good behavior. The educational level correlates with how easy an individual receives the information and implements it in the form of behavior and lifestyle [6]. Mother with a high level of education will have good KADARZI behavior. The good KADARZI behavior is shown by the children's nutritional status, which is in a good category. The disruption in nutritional status caused by the food consumption or malnutrition in toddler correlates with the mother's educational level [9]. Mother with a high level of education and in the productive category influence the better KADARZI behavior. Mother with the age 
ranged $<32$ years old and has a high level of education does positive behavior in giving the healthy and nutritious foods (vegetable and water) to the infants [10].

The working mother needs more time to do the activities outside the house, so it causes the less optimal of the parents' care to the children. Mother's care, which is less optimal, is not categorized as good behavior in taking care of the children [6]. The working mother has the least time to improve the knowledge about health, so it is difficult to make better behavior change [11]. The working mother gives less care to the children [12]. The working mother has the children whose nutritional status is lower than that of the unemployed mother [12]. The children's nutritional status is one of the indicators of KADARZI behavior. Malnutrition status is the form of KADARZI behavior.

Children birth spacing influences the quantity and the quality of the care and maternal care to the children. The children birth spacing less than 2 years causes less care given by the mother, and the breastfeeding for the children is not optimal [13]. The adequate children birth spacing is the protective factor of the malnutrition cases in toddler7.

\section{Conclusion}

The mother aged 20-35 years old, a mother with a high level of education, the unemployed mother, and the birth spacing of more or equal to 2 years lead to good KADARZI behavior. The implementation of good KADARZI behavior can improve the children's nutritional status, so they can thrive and develop according to their age.

Acknowledgments. We express our gratitude to our sponsor. All funds in this research were sourced from the Independent Research Grant of Universitas Sebelas Maret. We express our gratitude to all cadres of Posyandu in Tanjung Village Klego Sub-district Boyolali Regency, Midwives in Tanjung Village Klego Sub-district, and the staffs of Community Service Center (Puskesmas) in Klego Sub-district, Health Department of Boyolali Regency that has assisted the research permission and data collection

\section{References}

[1] Health Department of Republic Indonesia.: Keputusan Menteri Kesehatan Republik Indonesia Nomor :747/Menkes/SK/VI/2007 tentang pedoman operasional keluarga sadar gizi di keluarga. Direktorat Bina Gizi Masyarakat. (2007)

[2] Ministry of Health RI.:, Data dan Informasi Profil Kesehatan Indonesia 2017. (Jakarta. Pusat Data dan Informasi). (2018)

[3] Ministry of Health of Indonesian Republic.: Data dan informasi tahun Profil Kesehatan Indonesia 2014. (Jakarta: Pusat Data dan Informasi). (2015)

[4] Board of Health Research and Development, 2013, Penyajian Pokok-pokok Hasil Riset Kesehatan Dasar 2013 (Jakarta: Badan Penelitian dan Pengembangan Kesehatan).

[5] Noviyanti RD, Sarbini D.: Hubungan status gizi dengan status imunitas anak balita di RW VII Kelurahan Sewu Kecamatan Jebres Kota Surakarta. Jurnal Kesehatan. Vol. 3, pp. 58- 65. (2010)

[6] Wawan A, Dewi M.: Teori \& pengukuran pengetahuan sikap dan perilaku manusia (Yogjakarta: Nuha Medika). pp. 132. (2011)

[7] Kuntari T, Jamil NA, Sunarto, Kurniati O.: Faktor risiko malnutrisi pada balita. Jurnal Kesehatan Masyarakat Nasional. Vol. 7, pp. 572-5. (2013) 
[8] Jayati LD, Madanijah S, Khomsan A.: Pola Konsumsi pangan kebiasaan makan dan densitas gizi pada masyarakat Kesepuhan Ciptagelar Jawa Barat. Penelitian Gizi Pangan. Vol. 37, pp. 33-42. (2014)

[9] Mubarak WI.: Promosi kesehatan sebuah pengantar proses belajar mengajar dalam pendidikan (Yogyakarta: Graha Ilmu). pp. 416 (2007)

[10] Cameron A1, Ball K, Hesketh KD, McNaughton SA, Salmon J, Crawford DA, Lioret S, Campbell KJ.: Variation in outcomes of the Melbourne Infant, Feeding, Activity and Nutrition Trial (InFANT) Program according to maternal education and age. Vol. 58, pp. 58-63. (2014)

[11] Riauwi HM, Hasneli Y, Lestari W.: Efektivitas Pendidikan Kesehatan dengan Penerapan The Health Belief Model terhadap Pengetahuan Keluarga tentang Diare. JOM PSIK. Vol. 1, pp. 1-9. (2014)

[12] Nair M, Ariana P, Webster P.: Impact of mothers' employment on infant feeding and care: a qualitative study of the experiences of mothers employed through the Mahatma Gandhi National Rural Employment Guarantee Act. BMJ Open. Vol. 4, pp. 7-8. (2014)

[15] Proverawati A, Asfuah S.: Buku ajar gizi untuk kebidanan (Yogyakarta : Nuha Medika). pp.67-80. (2009) 